\title{
Synthesis, Characterization and Catalytic Properties of Cationic N-Heterocyclic Carbene Copper(I) Complex
}

\author{
Deniz Demir Atlı*, Şebnem E. Sözerli \\ Manisa Celal Bayar University, Faculty of Science and Letters, Department of Chemistry, 45140, Manisa, Turkey \\ *deniz.demir@cbu.edu.tr
}

Received: 09 November 2018

Accepted: 11 February 2019

DOI: $10.18466 /$ cbayarfbe. 480872

\begin{abstract}
A cationic $\mathrm{N}$-heterocyclic carbene copper(I) complex was prepared and characterized by FT-IR, ${ }^{1} \mathrm{H}$ NMR, ${ }^{13} \mathrm{C}$ NMR, elemental analysis and ESI/TOF mass spectrometry methods. Catalytic performances of the complex were studied in the [3+2] cycloaddition reaction of some azides and alkynes.
\end{abstract}

Keywords: N-heterocyclic carbene, copper(I), benzimidazol-2-ylidene, azide-alkyne cycloaddition.

\section{Introduction}

N-heterocyclic carbene (NHC) metal complexes are organometallic compounds which have strong metalcarbon bonds due to strong nucleophilic character of NHC ligands. Their transition metal complexes have wide usage in organometallic chemistry. The first NHC$\mathrm{Cu}(\mathrm{I})$ compound was prepared by the reaction of free 1,3dimesitylimidazol-2-ylidene and copper(I) triflate in 1993 [1]. They have exhibited catalytic efficiencies in many reactions such as hydrosilylation [2], allylic substitution [3], addition of S-H bonds to olefins [4], hydroboration [5] and carboxylation of organoboronic acid esters etc. [6].

[3+2] cycloaddition of azides and alkynes gives 1,2,3triazoles widely employed in medicinal chemistry [7, 8]. When this reaction proceeds with a copper(I) catalyst, 1,4-disubstituted-1H-1,2,3-triazole regioisomer is formed without byproduct. Various copper species have served as active catalysts in this transformation [9-12]. Also, NHC copper(I) complexes have led to 1,2,3triazoles [13]

In this paper, preparation of a cationic NHC copper(I) complex and preliminary catalytic tests in azide-alkyne cycloaddition reactions are reported. The structure of the $\mathrm{Cu}(\mathrm{I})$ complex is defined by FT-IR, ${ }^{1} \mathrm{H}$ NMR, ${ }^{13} \mathrm{C}$ NMR, ESI/TOF mass spectrometry and elemental analysis methods. The catalytic products are characterized by ${ }^{1} \mathrm{H}$ NMR and ${ }^{13} \mathrm{C}$ NMR analyses.

\section{Materials and Methods}

\subsection{General Considerations}

The synthesis of copper(I) complex was performed under argon atmosphere using flame-dried schlenk. 1 was synthesized according to a reported study by precipitating the product without removing of the solvent [14]. Ethyl 2-azidoacetate and phenyl azide were prepared by using of the literature methods $[15,16]$. THF and hexane were used after drying with suitable agents. The other solvents and the reagents were used without any purification. Elemental analysis was performed using a CHNS-932 (LECO) elemental analyzer. For ${ }^{1} \mathrm{H}$ NMR and ${ }^{13} \mathrm{C}$ NMR analyses, Varian $400 \mathrm{MHz}$ NMR spectrophotometer was employed. FT-IR spectrum was monitored on Perkin Elmer spectrophotometer at a range of $400-4000 \mathrm{~cm}^{-1}$. Molecular weight of the complex was determined by Bruker Daltonics MicroTof II instrument. Melting point measurement was made in a glass capillary tube under argon with Electrothermal 9100 apparatus.

\subsection{Synthesis of NHC-Cu(I) complex (2)}

A mixture of 1 (326 mg, $0.54 \mathrm{mmol}$ ), $\left[\mathrm{Cu}\left(\mathrm{CH}_{3} \mathrm{CN}\right)_{4}\right] \mathrm{BF}_{4}$ ( $85 \mathrm{mg}, 0.27 \mathrm{mmol}$ ) and $\mathrm{NaOBu}^{\mathrm{t}}(52 \mathrm{mg}, 0.54 \mathrm{mmol})$ in THF $(20 \mathrm{~mL})$ was stirred for $24 \mathrm{~h}$ at room temperature. After filtration through a plug of Celite, THF was removed under vacuum. The residue was crystallized from n-hexane at $+4{ }^{\circ} \mathrm{C}$. Yield: $0.29 \mathrm{~g}, 92 \%$. mp: $222-$ $223{ }^{\circ} \mathrm{C} .{ }^{1} \mathrm{H}$ NMR $\left(400 \mathrm{MHz}, \mathrm{CDCl}_{3}\right): \delta=7.17-6.99(\mathrm{~m}$, $20 \mathrm{H}, \mathrm{Ar}-\mathrm{H}), 5.62$ (s, 8H, $\left.\mathrm{NCH}_{2}\right), 1.08\left(\mathrm{~s}, 72 \mathrm{H}, \mathrm{CH}_{3}\right) \mathrm{ppm}$. ${ }^{13} \mathrm{C}$ NMR $\left(100 \mathrm{MHz}, \mathrm{CDCl}_{3}\right): \delta=151.29,135.59$, 134.64, 122.85, 122.05, 111.79, 53.55, 34.93, $31.61 \mathrm{ppm}$. ${ }^{19} \mathrm{~F}$ NMR $\left(100 \mathrm{MHz} \mathrm{CDCl}_{3}\right): \delta=114.24 \mathrm{ppm}$. FT-IR $(\mathrm{KBr}) v_{(\mathrm{C}=\mathrm{N})}: 1394 \mathrm{~cm}^{-1}$. ESI/TOF MS: $\left[\mathrm{M}-\mathrm{PF}_{6}-\mathrm{H}\right]$ at $\mathrm{m} / \mathrm{z}$ 1107.7. Anal. Calc. for $\mathrm{C}_{74} \mathrm{H}_{100} \mathrm{~N}_{4} \mathrm{CuBF}_{4}$ : C, 74.31; H, 8.43; N 4.69. Found: C, 71.68; H, 8.21; N, 4.44\%.

2.3. General procedure for $[3+2]$ cycloaddition of azides and alkynes

Azide $(1.0 \mathrm{mmol})$, alkyne $(1.1 \mathrm{mmol})$ and the catalyst ( $1.0 \mathrm{~mol} \%$ or $0.5 \mathrm{~mol} \%$ ) were put in a test tube with a lid. The mixture was stirred until the solidification was observed. It was dissolved in $\mathrm{CH}_{2} \mathrm{Cl}_{2}$ and n-pentane was added. The product was isolated by filtration, washing with n-pentane and drying under reduced pressure. The 
products, present compounds in the literature, were determined by ${ }^{1} \mathrm{H}$ NMR and ${ }^{13} \mathrm{C}$ NMR analyses [17-19].

\section{Ethyl 2-(4-phenyl-1H-1,2,3-triazol-1-yl)acetate}

${ }^{1} \mathrm{H}$ NMR (400 MHz, $\left.\mathrm{CDCl}_{3}\right): \delta=7.98(\mathrm{~s}, 1 \mathrm{H}$, triazole), 7.85 (d, J = 7.08 Hz, 2H, Ar-H), 7.42 (t, J = 7.12 Hz, 2H, Ar-H), 7.33 (t, J = $7.34 \mathrm{~Hz}, 1 \mathrm{H}, \mathrm{Ar}-\mathrm{H}), 5.18(\mathrm{~s}, 2 \mathrm{H}$, $\mathrm{NCH}_{2}$ ), 4.26 (q, J = 7.14 Hz, 2H, $\left.\mathrm{CO}_{2} \mathrm{CH}_{2} \mathrm{CH}_{3}\right), 1.29$ (t, $\left.\mathrm{J}=7.13 \mathrm{~Hz}, 3 \mathrm{H}, \mathrm{CO}_{2} \mathrm{CH}_{2} \mathrm{CH}_{3}\right)$ ppm. ${ }^{13} \mathrm{C}$ NMR (100 $\left.\mathrm{MHz}, \mathrm{CDCl}_{3}\right): \delta=166.49,159.17,130.75,129.05$ 125.97, 99.11, 62.62, 51.27, $14.27 \mathrm{ppm}$.

\section{Ethyl 2-(4-butyl-1H-1,2,3-triazol-1-yl)acetate}

${ }^{1} \mathrm{H}$ NMR (400 MHz, $\left.\mathrm{CDCl}_{3}\right): \delta=7.47(\mathrm{~s}, 1 \mathrm{H}$, triazole), $5.11\left(\mathrm{~s}, 2 \mathrm{H}, \mathrm{NCH}_{2}\right), 4.24(\mathrm{q}, \mathrm{J}=7.15 \mathrm{~Hz}, 2 \mathrm{H}$, $\left.\mathrm{CO}_{2} \mathrm{CH}_{2} \mathrm{CH}_{3}\right), 2.75-2.71\left(\mathrm{~m}, 2 \mathrm{H}, \mathrm{CH}_{2}\right), 1.69-1.66(\mathrm{~m}, 2 \mathrm{H}$, $\left.\mathrm{CH}_{2}\right), 1.43-1.34\left(\mathrm{~m}, 2 \mathrm{H}, \mathrm{CH}_{2}\right), 1.28(\mathrm{t}, \mathrm{J}=7.13 \mathrm{~Hz}, 3 \mathrm{H}$, $\left.\mathrm{CO}_{2} \mathrm{CH}_{2} \underline{\mathrm{CH}}_{3}\right), 0.92\left(\mathrm{t}, \mathrm{J}=7.31 \mathrm{~Hz}, 3 \mathrm{H}, \mathrm{CH}_{3}\right) \mathrm{ppm} .{ }^{13} \mathrm{C}$ NMR $\left(100 \mathrm{MHz}, \mathrm{CDCl}_{3}\right): \delta=166.69,109.99,62.47$, $51.00,31.63,25.52,22.45,14.24,13.98$ ppm.

\section{1-benzyl-4-phenyl-1H-1,2,3-triazole}

${ }^{1} \mathrm{H}$ NMR (400 MHz, $\left.\mathrm{CDCl}_{3}\right): \delta=7.81(\mathrm{~d}, \mathrm{~J}=7.28 \mathrm{~Hz}$, 2H, Ar-H), 7.71 (s, 1H, triazole), 7.41-7.28 (m, 8H, Ar$\mathrm{H}), 5.54\left(\mathrm{~s}, 2 \mathrm{H}, \mathrm{NCH}_{2}\right) \mathrm{ppm} .{ }^{13} \mathrm{C} \mathrm{NMR}(100 \mathrm{MHz}$, $\left.\mathrm{CDCl}_{3}\right): \delta=134.99,130.88,129.34,129.04,128.96$, 128.37, 128.26, 125.91, $54.43 \mathrm{ppm}$.

\section{1,4-diphenyl-1H-1,2,3-triazole}

${ }^{1} \mathrm{H}$ NMR (400 MHz, $\left.\mathrm{CDCl}_{3}\right): \delta=8.19(\mathrm{~s}, 1 \mathrm{H}$, triazole), $7.92(\mathrm{~d}, \mathrm{~J}=7.20 \mathrm{~Hz}, 2 \mathrm{H}, \mathrm{Ar}-\mathrm{H}), 7.80(\mathrm{~d}, \mathrm{~J}=7.51 \mathrm{~Hz}$, 2H, Ar-H), 7.57-7.53 (m, 2H, Ar-H), 7.48-7.45 (m, 3H, Ar-H), 7.39-7.35 (m, 1H, Ar-H) ppm. ${ }^{13} \mathrm{C}$ NMR (100 $\left.\mathrm{MHz}, \mathrm{CDCl}_{3}\right): \delta=148.65,137.33,130.50,129.99$, 129.13, 128.98, 128.64, 126.09, 120.76, 117.81 ppm.

\section{Results and Discussion}

Synthesis of NHC copper(I) complex is shown in scheme 1. The reaction of $\left[\mathrm{Cu}\left(\mathrm{CH}_{3} \mathrm{CN}\right)_{4}\right] \mathrm{BF}_{4}$ with two equivalents of the benzimidazolium salt $\mathbf{1}$ in the presence of $\mathrm{NaOBu}^{\mathrm{t}}$ gave the cationic bis(NHC) copper(I) complex in $92 \%$ yield. The compound is soluble in $\mathrm{CH}_{2} \mathrm{Cl}_{2}$, THF, toluene, DMSO and DMF and insoluble in $\mathrm{Et}_{2} \mathrm{O}$ and n-pentane.

Structure of the compound was elucidated by ${ }^{1} \mathrm{H}$ NMR, ${ }^{13} \mathrm{C}$ NMR, FT-IR, elemental analysis and ESI/TOF mass methods. Unfortunately, a single crystal could not be obtained for x-ray diffraction analysis despite all our efforts. In the ${ }^{1} \mathrm{H}$ NMR spectrum, absence of the peak related to the acidic NCHN proton is an evidence for formation of a carbene complex (Figure 1). Singlet signals present at 5.62 and $1.08 \mathrm{ppm}$ in the ${ }^{1} \mathrm{H}$ NMR spectrum refer to the methylene protons and $\mathrm{Bu}^{\mathrm{t}}$ protons, respectively.<smiles></smiles>

1

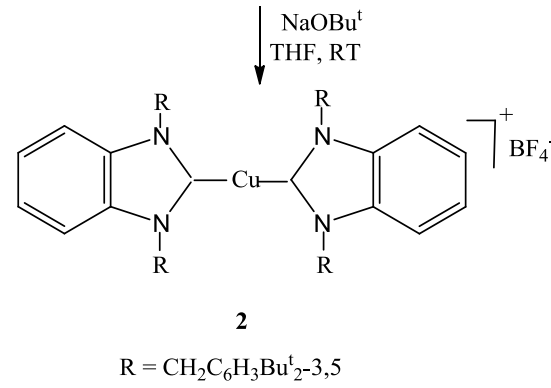

Scheme 1. Synthesis of the copper(I) complex.

In the ${ }^{13} \mathrm{C}$ NMR spectrum, chemical shift values for methylene and $\mathrm{Bu}^{\mathrm{t}}$ groups are 53.55, 34.93 and 31.61 ppm (Figure 2). $\mathrm{C}_{\text {carbene }}$ chemical shift is not observed in the ${ }^{13} \mathrm{C}$ NMR spectrum. This situation has been previously reported [20]. The peaks existing at 2962 $\mathrm{cm}^{-1}$ and $1394 \mathrm{~cm}^{-1}$ are related to the stretching vibrations of the $\mathrm{Bu}^{\mathrm{t}}$ group and $-\mathrm{C}=\mathrm{N}-$ groups in the FT-IR spectrum [14]. The ESI/TOF mass spectrum affirms the formation of $\left[(\mathrm{NHC})_{2} \mathrm{Cu}\right]^{+}$ion (Figure 3).

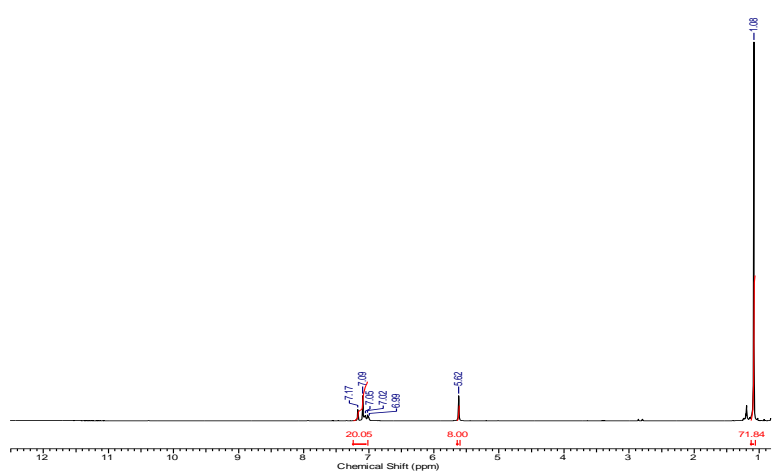

Figure 1. ${ }^{1} \mathrm{H}$ NMR spectrum of the copper(I) complex.

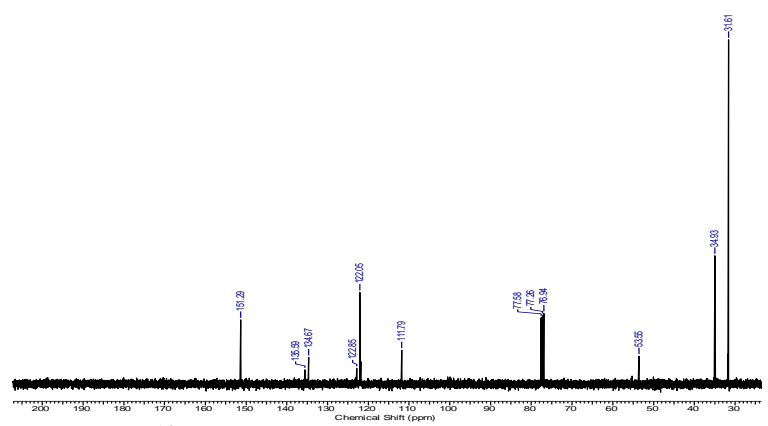

Figure 2. ${ }^{13} \mathrm{C}$ NMR spectrum of the copper(I) complex. 


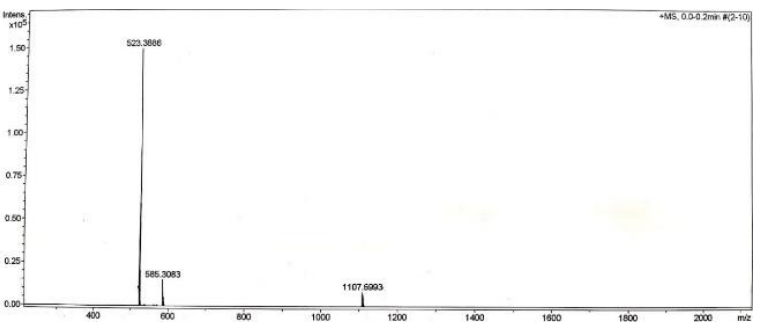

Figure 3. ESI/TOF mass spectrum of the copper(I) complex.

Table 1. NHC-copper(I) catalyzed [3+2] cycloaddition of some azides and alkynes ${ }^{\text {a }}$

$$
\mathrm{R}-\mathrm{N}_{3}+\equiv \mathrm{R}^{\prime} \stackrel{\mathrm{Cu}(\mathrm{I})}{\longrightarrow}
$$

\begin{tabular}{lllll}
\hline Entry & $\mathrm{R}$ & $\mathrm{R}^{\prime}$ & $\begin{array}{l}\text { Time } \\
(\text { min })\end{array}$ & $\begin{array}{l}\text { Yield } \\
(\%)\end{array}$ \\
\hline 1 & $\mathrm{CH}_{2} \mathrm{CO}_{2} \mathrm{Et}$ & $\mathrm{Ph}$ & 25 & $61^{\mathrm{b}}$ \\
2 & $\mathrm{CH}_{2} \mathrm{CO}_{2} \mathrm{Et}$ & $\mathrm{Ph}$ & 10 & 92 \\
3 & $\mathrm{CH}_{2} \mathrm{CO}_{2} \mathrm{Et}$ & n-Bu & 330 & 95 \\
4 & $\mathrm{Bn}$ & $\mathrm{Ph}$ & 60 & 74 \\
5 & $\mathrm{Ph}$ & $\mathrm{Ph}$ & 15 & 88 \\
\hline
\end{tabular}

${ }^{a}$ Reaction conditions: $1.0 \mathrm{mmol}$ azide, $1.1 \mathrm{mmol}$ alkyne, NHC-Cu(I) catalyst $(1 \mathrm{~mol} \%)$, RT. ${ }^{\mathrm{b}} \mathrm{NHC}-\mathrm{Cu}(\mathrm{I})$ catalyst $(0.5 \mathrm{~mol} \%)$.

The reaction of ethyl 2-azidoacetate and phenylacetylene to give 2-(4-phenyl-1H-1,2,3-triazol-1-yl)acetate was realised using $1 \mathrm{~mol} \%$ and $0.5 \mathrm{~mol} \%$ catalyst at room temperature (Table 1, entries 1,2). High yield was obtained with $1 \mathrm{~mol} \%$ catalyst in a short time of 10 minutes. The reactions of phenylacetylene with benzyl azide and phenyl azide substrates led to the corresponding 1,2,3-triazoles in high yields (Table 1, entries 4, 5). Ethyl 2-azidoacetate with electronwithdrawing group gave the cycloaddition product in shorter time than benzyl azide and phenyl azide [10]. The copper(I) complex displayed high activity in the reaction of ethyl 2-azidoacetate with 1-hexyne (Table 1, entry 3 ). This reaction is slower than that of ethyl 2-azidoacetate with phenyl azide because of using electon rich azide [13].

\section{Conclusion}

In conclusion, we synthesized a cationic NHC copper(I) complex containing benzimidazol-2-ylidene. The structure of the compound was determined by ${ }^{1} \mathrm{H}$ NMR, ${ }^{13} \mathrm{C}$ NMR, ${ }^{19} \mathrm{~F}$ NMR, elemental analysis and ESI/TOF mass spectrometry. Preliminary catalytic studies revealed that the copper(I) complex gave 1,2,3-triazoles in good yields at room temperature under neat conditions.

\section{Acknowledgements}

This work was supported by Scientific Research Project of Manisa Celal Bayar University. Project No: FBE 2008/72.

\section{Author's Contribution}

Deniz Demir Atli: Performed the experiment, interpreted to the results, drafted and wrote the manuscript.

Şebnem E. Sözerli: Supervised the experiment's progress, result interpretation.

\section{Ethics}

There are no ethical issues after the publication of this manuscript.

\section{References}

1. Arduengo III, AJ, Dias, HVR, Calabrese, JC, Davidson, F. 1993. Homoleptic carbene-silver(I) and carbene-copper(I) complexes. Organometallics; 12: 3405-3409.

2. Trose, M, Nahra, F, Poater, A, Cordes, DB, Slawin, AMZ, Cavallo, L, Cazin, CSJ. 2017. Investigating the structure and reactivity of azolyl-based copper(I)-NHC complexes: The role of the anionic ligand. ACS Catalysis; 7: 8176-8183.

3. Delvos, LB, Oestreich, M. 2015. Temperature-dependent direct enantioconvergent silylation of a racemic cyclic allylic phosphate by copper(I) catalyzed allylic substitution. Synthesis-Stuttgart; 47: 924-933.

4. Delp, SA, Munro-Leighton, C, Goj, LA, Ramirez, MA, Gunnoe, TB, Petersen, JL, Boyle, PD. 2007. Addition of S-H bonds across electron-deficient olefins catalyzed by well-defined copper(I) thiolate complexes. Inorganic Chemistry; 46: 2365-2367.

5. Jang, H, Zhugralin, AR, Lee, Y, Hoveyda, AH. 2011. Highly selective methods for synthesis of internal $(\alpha-)$ vinylboronates through efficient $\mathrm{NHC}-\mathrm{Cu}$-catalyzed hydroboration of terminal alkynes. Utility in chemical synthesis and mechanistic basis for selectivity. Journal of American Chemical Society; 133: 78597871.

6. Wang, W, Zhang, G, Lang, R, Xia, C, Li, F. 2013. pH-responsive $\mathrm{N}$-heterocyclic carbene copper(I) complexes: syntheses and recoverable applications in the carboxylation of arylboronic esters and benzoxazole with carbon dioxide. Green Chemistry; 15: 635640 .

7. Lewis, WG, Green, LG, Radic, Z, Carlier, PR, Taylor, P, Finn, MG, Sharpless, KB. 2002. Click chemistry in situ: Acetylcholinesterase as a reaction vessel for the selective assembly of a femtomolar inhibitor from an array of building blocks. Angewandte Chemie International Edition; 41: 1053-1057.

8. Whiting, M, Muldoon, J, Lin, Y-C, Silverman, SM, Lindstrom, W, Olson, AJ, Kolb, HC, Finn, MG, Sharpless, KB, Elder, JH. 2006. Inhibitors of HIV- 1 protease by using In situ Click chemistry. Angewandte Chemie International Edition; 45: 1435-1439.

9. Demir Atlı, D. 2018. Synthesis and characterization of benzimidazolium salts bearing triazole groups. Celal Bayar University Journal of Science; 14: 57-60.

10. Golas, PL, Tsarevsky, NV, Matyjaszewski, K. 2008. Structurereactivity correlation in "Click" chemistry: Substituent effect on azide reactivity. Macromolecular Rapid Communications; 29: 1167-1171. 
11. Pasupuleti, BG, Bez, G. 2019. CuI/L-proline catalyzed click reaction in glycerol for the synthesis of 1,2,3-triazoles. Tetrahedron Letters; 60: 142-146.

12. Nia, AS, Rana, S, Döhler, D, Jirsa, F, Meister, A, Guadagno, L, Koslowski, E, Bron, M, Binder, WH. 2015. Carbon- supported copper nanomaterials: Recyclable catalysts for Huisgen [3+2] cycloaddition reactions. Chemistry-A European Journal; 21: 10763-10770.

13. Diez-Gonzalez, S, Escudero-Adan, EC, Benet-Buchholz, J, Stevens, ED, Slawin, AMZ, Nolan, SP. 2010. [(NHC)CuX] complexes: Synthesis, characterization and catalytic activities in reduction reactions and Click chemistry. On the advantage of using well-defined catalytic systems. Dalton Transactions; 39: 75957606.

14. Kaloğlu, N, Özdemir, İ, Günal, S, Özdemir, İ. 2017. Synthesis and antimicrobial activity of bulky 3,5- di- tert- butyl substituentcontaining silver-N- heterocyclic carbene complexes. Applied Organometallic Chemistry; 31: e3803.

15. Kwok, SW, Fotsing, JR, Fraser, RJ, Rodionov, VO, Fokin, VV. 2010. Transition-metal-free catalytic synthesis of 1,5-diaryl-1,2,3triazoles. Organic Letters; 12: 4217-4219.

16. Alvarez, SG, Alvarez, MT. 1997. A practical procedure for the synthesis of alkyl azides at ambient temperature in dimethyl sulfoxide in high purity and yield. Synthesis; 4: 413-414.

17. Shao, C, Wang, X, Xu, J, Zhao, J, Zhang, Q, Hu, Y. 2010. Carboxylic Acid-Promoted Copper(I)-Catalyzed Azide-Alkyne Cycloaddition. Journal of Organic Chemistry; 75: 7002-7005.

18. Adzima, BJ, Tao, Y, Kloxin, CJ, DeFrorest, CA, Anseth, KS, Bowman, CN. 2011. Spatial and temporal control of the alkyneazide cycloaddition by photoinitiated $\mathrm{Cu}(\mathrm{II})$ reduction. Nature Chemistry; 3: 256-259.

19. Wang, D, Li, N, Zhao, M, Shi, W, Ma, C, Chen, B. 2010. Solventfree synthesis of 1,4-disubstituted 1,2,3-triazoles using a low amount of $\mathrm{Cu}\left(\mathrm{PPh}_{3}\right)_{2} \mathrm{NO}_{3}$ complex. Green Chemistry; 12: 21202123.

20. Liu, B, Ma, X, Wu, F, Chen, W. 2015. Simple synthesis of neutral and cationic Cu-NHC complexes. Dalton Transactions, 44: 18361844. 